\title{
GROWTH OF FOUR TREE SPECIES ON MEDIA CONTAINING GOLD MINE TAILING OF PT ANTAM UBPE PONGKOR
}

\author{
Ulfah Juniarti Siregar and Roisatuz Zakiyah* \\ Department of Silviculture, Bogor Agricultural University, Bogor, 16680, Indonesia \\ *Corresponding author: roisatuzzakiyah94@gmail.com
}

\begin{abstract}
PT Antam UBPE Pongkor is a gold mining company that produces waste in the from of tailing mud which contains heavy metal with sufficiently high concentration. The aim of this research was to study the growth of four types of plant, i.e. Casuarina junghuniana, Pinus merkusii, Melia azedarach, and Gmelina arborea in a media containing tailing mud. This research used a completely randomized factorial design with two factors, i.e. types of plant and media. Two kinds of media was used i.e. $1200 \mathrm{~g}$ tailing and a mixture of $900 \mathrm{~g}$ tailing and $300 \mathrm{~g}$ compost. Growth parameters observed were plant diameter, height, number of leaf, leaf lenght and widht, total wet and dry biomass, root-shoot-ratio and number of stomata. Soil and plant analysis was done after four months of experiment. The results showed that plant types have significant effects on all parameters except root-shoot-ratio and plant height. Media types significantly affect plant diameter, wet and dry biomass. Interaction between plant types and media gave sifnificant effect on diameter, wet and dry biomass. G. arborea had the best growth response on all parameters except root-shoot-ratio and plant heigh. Its average diameter was $4.56 \mathrm{~mm}$, leaf lenght $3.67 \mathrm{~cm}$, leaf widht $3.000 \mathrm{~cm}$, total wet biomass $50.21 \mathrm{~g}$, total dry biomass $32.19 \mathrm{~g}$ and number of stomata is 89 .
\end{abstract}

Key words: C. junghuniana, G. arborea, metal, M. azedarach, tailing, P. merkusii.

\section{INTRODUCTION}

Environmental degradation, especially due to mining activities draws special attention from the Government, because often is not addressed properly in Indonesia. The mining activities damage environment mostly by removing the above ground vegetation, followed by excavation of the land removing the upper layer of the soil, and then dumping wastes from the process of mining on the ground level. Results of mining activities often create the so-called B3 wastes in Indonesian, which is dangerous, toxic and hazardous materials. The wastes often contain heavy metals and cause environmental pollution.

PT Antam UBPE Pongkor is a gold mining company that deposits tailing mud in a tailing dam. The tailing might contain high number of metal such as $\mathrm{Hg}, \mathrm{Pb}, \mathrm{Fe}$, $\mathrm{Mn}, \mathrm{Zn}$, and $\mathrm{Cu}$, which are toxic to the environment. Management of such toxic wastes is important to curb the negative impact. One way to manage waste pollution is using plants in a process called phytoremediation. Phytoremediation is a process to contain, reduce or eliminate high concentration of toxic or heavy metals in the soil by growing some plants. Some plants are known to have high capability to grow in a polluted environment due to have tolerance mechanism against pollution. The plant is considered tolerant if they are able to grow in soil with high metal accumulation without distrubing the growth of the plants itself.

Mountain Cemara (Casuarina junghuniana), Pines (Pinus merkusii), Mindi (Melia azedarach), and
Gmelina (Gmelina arborea) are four fast growing trees which are usually used to rehabilitate degraded land in Indonesia. The aim of this research was to study the growth of four types of plant, i.e. Casuarina junghuniana, Pinus merkusii, Melia azedarach, and Gmelina arborea in an ex gold mining tailing mud.

\section{MATERIALS AND METHODS}

The research started in November 2014 until March 2015 in the greenhouse belongs to Laboratory of Forest Ecology at Department of Silviculture, Faculty of Forestry IPB. Stomata observation was conducted at Department of Agronomy and Horticulture, Faculty of Agriculture IPB.

\section{Plant Materials}

Plant materials were 3 months old seedling of Mountain Cemara (C. junghuniana), Pine (P. merkusii), Gmelina ( $G$. arborea) dan Mindi ( $M$. azedarach) obtained from Dramaga Permanent Nursery. The seedlings of each species were relatively uniform in their diameter and height.

\section{Experimental Procedure}

The media in this experiment consisted of two kinds, i.e. tailings taken from tailings dam of PT Antam UBPE Pongkor, at Cikaret, Bogor, Indonesia and a mixture of tailing and compost. The media was prepared in a in a 
$20 \mathrm{~cm} \times 20 \mathrm{~cm}$ polybags, each contains either $1200 \mathrm{~g}$ tailing or a mixture of $900 \mathrm{~g}$ tailing and $300 \mathrm{~g}$ compost. Procured seedlings were transferred carefully as to not damaging their roots from their original container into experimental media. Seedlings were maintained by spraying water every day.

Parameters observed included plant height, diameter, number of leaves, leaf length and width, stomata density, total wet and dry biomass and shoot-root ratio. Plant diameter was measured using digital caliper at a position of $2 \mathrm{~cm}$ above the media surface for pine seedling, while for the other seedlings at $5 \mathrm{~cm}$ above the surface.

Measurement of plant height was done from the base of the main stem until the end of the apical shoot. A sign was put at the base of the main stem for measurement consistency. Number of leaves was counted by counting all leaves growing on a seedling. Leaf length and width were measured once a month on selected leaves which are already fully developed at the top of the seedlings and then averaged. Stomata were calculated using ordinary microscope with $40-x$ lens on four randomly selected plants from each treatment.

To measure the plant biomass, plant samples were harvested, and then each tissues were separated, i.e. roots, leaves, and stems. Roots were weighted separately from stems and leaves. Wet biomass was calculated from total weight of all tissues. After wet biomass was obtained, each tissue samples were dried in an oven at $75{ }^{\circ} \mathrm{C}$ for 24 hours. Dried samples were then weighted in order to measure dry biomass. Root-shoot ratio was calculated from ratio between root dry weight and sum of stem and leaves dry weight.

The experiment adopted completely randomized design (CRD) with two factors, i.e. media and plant species.

Media :

A1 : tailing $(1200 \mathrm{~g})$

A2 : tailing $(900 \mathrm{~g})+$ compost $(300 \mathrm{~g})$

The plant species:

P1 : Mountain Cemara (C. junghuniana)

P2 : Pines (P. merkusii)

P3 : Mindi (M. azedarach)

P4 : Gmelina (G. arborea)

The model for the experiment is as followed:

$Y i j k=\mu+\alpha i+\beta j+(\alpha \beta) i j+\varepsilon i j k$

Treatment effect on parameters observed was analysed with F-test:

a. P-value $>\alpha(0.05)$ shows the effect of treatment was not significant.

b. P-value $<\alpha(0.05)$ shows the treatment gave significant influence, and continue analysis using Duncan test.

Data was recorded in software MS. Excel 2010 and then analyzed using SAS 9.0.

\section{RESULT AND DISCUSSION}

Plant growth can be defined as an increase of volume, mass, amount of protoplasm, or the number of cells (Salisbury and Ross 1995). Two dimensions that are commonly used to measure the growth are increase in volume and mass. Added volume is determined by measuring the magnification such as plant height, stem diameter, and leaf length. Added mass is often determined by measuring the wet and dry weight of a plant.

Table 1 Summary of ANOVA of the treatments effect on plant growth parameters, growing for 4 months

\begin{tabular}{lccc}
\hline \multirow{2}{*}{ Parameters } & \multicolumn{3}{c}{ Treatments } \\
\cline { 2 - 4 } & $\mathrm{P}$ & $\mathrm{M}$ & $\mathrm{P}+\mathrm{M}$ \\
\hline Height $(\mathrm{cm})$ & $* *$ & $\mathrm{~ns}$ & $\mathrm{~ns}$ \\
Diameter $(\mathrm{mm})$ & $* *$ & $\mathrm{~ns}$ & $*$ \\
Leaf lenght $(\mathrm{cm})$ & $* *$ & $*$ & $\mathrm{~ns}$ \\
Leaf widht $(\mathrm{cm})$ & $* *$ & $\mathrm{~ns}$ & $\mathrm{~ns}$ \\
Wet biomass $(\mathrm{g})$ & $* *$ & $* *$ & $*$ \\
Dry biomass $(\mathrm{g})$ & $* *$ & $* *$ & $*$ \\
Root-shoot-ratio & $\mathrm{ns}$ & $\mathrm{ns}$ & $\mathrm{ns}$ \\
\hline
\end{tabular}

Note: $\mathrm{P}=$ plant types; $\mathrm{M}=$ Media; $* *=$ highly significant at $\mathrm{P}$-value $<0.01 ; *=$ significant at $\mathrm{P}$ value $<0.05 ; \mathrm{ns}=$ not significant

Table 1 shows that plants species had highly significant influence on all parameters, except rootshoot ratio. Media significantly influenced growth of leaf length, total wet and dry weight. Interactions between plants types with media significantly influenced growth of diameter, wet and dry biomass.

Original height and diameter of each species were different, especially P. merkusii (P2) which had lowest height and diameter among all. Therefore growth value was obtained from subtracting current measurement with original height and diameter of each individual plants.

Table 2 Average growth of diameter and height of four plant types grown for 4 months on media containing tailing

\begin{tabular}{lcc}
\hline Treatments & $\begin{array}{c}\text { Diameter } \\
(\mathrm{mm})\end{array}$ & $\begin{array}{c}\text { Height } \\
(\mathrm{cm})\end{array}$ \\
\hline P4 $($ G. arborea $)$ & $4.5617 \mathrm{a}$ & $36.362 \mathrm{~b}$ \\
P3 $($ M. azedarach $)$ & $3.1767 \mathrm{~b}$ & $40.863 \mathrm{a}$ \\
P1 $($ C.junghunian $)$ & $1.1083 \mathrm{c}$ & $8.205 \mathrm{c}$ \\
P2 $(P$. merkusii $)$ & $0.7167 \mathrm{~d}$ & $1.318 \mathrm{~d}$
\end{tabular}

NOTE: different letters in the same column indicates significant effect at $99 \%$ confidence.

Table 2 shows $G$. arborea had the highest diameter growth compared to other plants with an average value of $4.5617 \mathrm{~mm}$. However highest height growth was on $M$. azedarach with a value of $40.863 \mathrm{~cm}$, while the lowest was $P$. merkusii with a value of $1.318 \mathrm{~cm}$. Both $G$. arborea and $M$. azedarach are fast growing tree species. Influence of the treatments interaction on diameter growth are presented in Table3. 
Table 3 Influence of treatments interaction on diameter growth of seedlings grown for 4 months

\begin{tabular}{lc} 
Treatments & Average Diameter Growth $(\mathrm{mm})$ \\
\hline $\mathrm{P} 4 \mathrm{~A} 2$ & $5.0433 \mathrm{a}$ \\
$\mathrm{P} 4 \mathrm{~A} 1$ & $4.0800 \mathrm{~b}$ \\
$\mathrm{P} 3 \mathrm{~A} 1$ & $3.4300 \mathrm{c}$ \\
$\mathrm{P} 3 \mathrm{~A} 2$ & $2.9233 \mathrm{~d}$ \\
$\mathrm{P} 1 \mathrm{~A} 2$ & $1.1600 \mathrm{e}$ \\
$\mathrm{P} 1 \mathrm{~A} 1$ & $1.0567 \mathrm{e}$ \\
$\mathrm{P} 2 \mathrm{~A} 1$ & $0.7267 \mathrm{e}$ \\
$\mathrm{P} 2 \mathrm{~A} 2$ & $0.7067 \mathrm{e}$ \\
\hline
\end{tabular}

.NOTE: A1: tailing media; A2; mix media; P1: $C$. junghuniana; $\mathrm{P} 2$ : $P$. merkusii; $\mathrm{P} 3 ; \quad M$. azedarach; P4: G. arborea; different letters in the same column indicates significant effect at $95 \%$ confidence.

Table 3 shows that P4A2 (G. arborea on mix media) gave highest diameter value of $5.0433 \mathrm{~mm}$, while lowest diameter belonged to $C$. junghuniana on mix media. Both $C$. junghuniana and $P$. merkusii gave lower growth and did not differ significantly on both media, because those two species have slow growth habit. G. arborea on the contrary is one of fast-growing tree species, of which diameter at the age of 18 months in the field reach $6.4 \mathrm{~cm}$ (Suhendi 1995 in Dharmawan 2003). Dharmawan (2003) found out that G. arborea grow best on media containing tailing and compost with ratio $3: 1$. Compost could boost soil fertility and stimulate healthy roots (Wasis et al. 2011).

Table 4 Average growth of leaf length and width of four plant species grown for 4 months

\begin{tabular}{lcc}
\hline Treatment & $\begin{array}{c}\text { Leaf length } \\
(\mathrm{cm})\end{array}$ & $\begin{array}{c}\text { Leaf width } \\
(\mathrm{cm})\end{array}$ \\
\hline $\mathrm{P} 4($ G. arborea $)$ & $3.00 \mathrm{a}$ & $3.000 \mathrm{a}$ \\
$\mathrm{P} 1($ C. junghuniana $)$ & $2.93 \mathrm{~b}$ & na \\
P2 $($ P. merkusii $)$ & $1.83 \mathrm{~b}$ & na \\
P3 $($ M. azedarach $)$ & $1.00 \mathrm{c}$ & $0.667 \mathrm{~b}$ \\
\hline
\end{tabular}

NOTE: different letters in the same column indicates significant effect at $95 \%$ confidence

Number of leaves, leaf length and width as a photosynthetic organ can be used for indicators of plant growth (Sitompul and Guritno 1995) since photosynthetic product is component of biomass accumulation. Leaf length and width represents leaf shape of certain plant. Leaf width was available on $G$. arborea and M. azedarach only as the other plants have needles. Table 5 shows that highest growth on leaf length and width was on G. arborea. Among plant species having needles $C$. junghuniana had higher growth than P. merkusii. Table 5 shows effects of media on the growth of leaf length. Mix media apparently gave better growth of leaf lenght than tailing media.
Table 5 Effect of media on growth of seedlings leaf lenght grown for 4 months

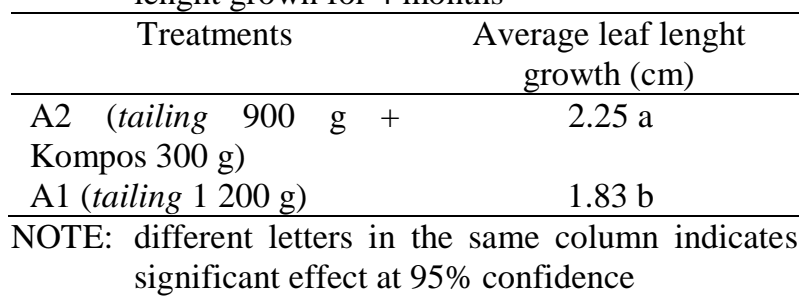

Diagram in Figure 1 shows the number of leaves of each experimental unit in 6 weeks observation. Almost all treatment combination showed increasing number of leaves, except P3A1 and P3A2 with decreasing trend, because $M$. azedarach undergone leaf fall of old leaves. The falling leaves showed normal symptoms started by discoloration of the leaf into yellowing. It might be a symptom of toxic intake, because Widyati (2011) reported that excess absorption of $\mathrm{Fe}, \mathrm{Cu}$, and $\mathrm{Zn}$ in $\mathrm{A}$. crassicarpa caused leaf yellowing in the plant.

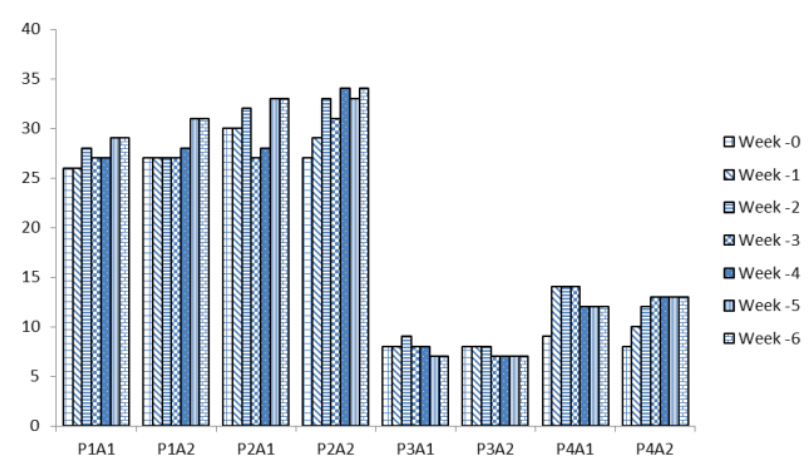

Figure 1 Diagram of number of leaves from treatment combination of seedlings grown for 4 months. NOTE: A1: tailing media; A2; mix media; P1: C. junghuniana; P2: P. merkusii; P3; M. azedarach; P4: G. arborea;

Stomata is an opening in the epidermis tissues flanked by two guard cells which usually function as regulator of plant transpiration, and mostly located in leaves (Pindey 1982 in Haryanti 2010). The number of stomata constitutes stomata density and is related to transpiration rate of a plant. The results of stomata density is presented in Table 6 .

Table 6 Stomata density of four plant species grown on media containing tailing for 4 months

\begin{tabular}{lrrr}
\hline Treatments & Control & $\begin{array}{c}\text { Media } \\
\text { Tailing }\end{array}$ & $\begin{array}{c}\text { Mix } \\
\text { Media }\end{array}$ \\
\hline P1 (C. junghuniana) & 19 & 64 & 55 \\
P2 (P. merkusii) & 7 & 15 & 11 \\
P3 $($ M. azedarach) & 47 & 49 & 38 \\
P4 (G. arborea) & 62 & 86 & 89 \\
\hline
\end{tabular}

Note: Control is a plant that is planted on the soil without treatment

Table 6 shows G. arborea had highest stomata among other plants. Siregar and Siregar (2010) explained that high transpiration of a fast-growing plant is a mechanism of water and nutrient transfer system in the plant. Transpiration speed is directly proportional to 
the ability of the absorption of the plants against heavy metal. The higher the rate of transpiration in a plant the bigger ability of the absorption of the metal is expected in that plant.

Total wet or dry biomass is the result a summation between shoot and root wet or dry weight. Dry biomass is the parameter used to know plant growth, because it reflects physiological efficiency in plants (Wulandari and Susanti 2012). Effect of treatments interaction on both wet and dry biomass is presented in Table 7.

Table 7 The effect of treatments interaction on total wet and dry biomass of four plant species grown for 4 months

\begin{tabular}{|c|c|c|}
\hline Treatments & $\begin{array}{c}\text { Average total } \\
\text { wet biomass }(\mathrm{g})\end{array}$ & $\begin{array}{l}\text { Average total dry } \\
\text { biomass }(\mathrm{g})\end{array}$ \\
\hline P4A2 & $50.210 \mathrm{a}$ & $32.193 \mathrm{a}$ \\
\hline P4A1 & $38.403 \mathrm{~b}$ & $24.677 \mathrm{~b}$ \\
\hline P3A2 & $28.977 \mathrm{c}$ & $15.363 \mathrm{c}$ \\
\hline P3A1 & $25.677 \mathrm{c}$ & $13.540 \mathrm{c}$ \\
\hline P1A2 & $17.487 \mathrm{~d}$ & $10.510 \mathrm{~d}$ \\
\hline P1A1 & $16.980 \mathrm{~d}$ & $10.163 \mathrm{~d}$ \\
\hline $\mathrm{P} 2 \mathrm{~A} 1$ & $3.240 \mathrm{e}$ & $2.493 \mathrm{e}$ \\
\hline P2A2 & $3.040 \mathrm{e}$ & $2.310 \mathrm{e}$ \\
\hline NOTE: A1: & $\begin{array}{l}\text { ailing media; } \mathrm{A} 2 \\
\text { uniana; } \mathrm{P} 2: \\
\text { rach; } \mathrm{P} 4: \text { G. arbo } \\
\text { me column indica } \\
\text { onfidence }\end{array}$ & $\begin{array}{l}\text { mix media; P1: } \\
\text { merkusii; P3; } \\
\text { a; different letters } \\
\text { significant effect }\end{array}$ \\
\hline
\end{tabular}

P4A2 treatment ( $G$. arborea on mix media) showed the best response compared to the same species on tailing media. In general, media mix media, which contains compost, gave better growth on all plants. The only exception is $P$. merkusii, of which tailing media was better than mix media, however the difference between different media was not significant.

Shoot- Root-Ratio (SRR) is a value used to know a balance growth between the tops of the plant as the location of transpiration and photosynthesis with the root part as the place of water and nutrient absorption (Setyaningsih 2007). Average SRR of every treatment combination is presented in Figure 2.

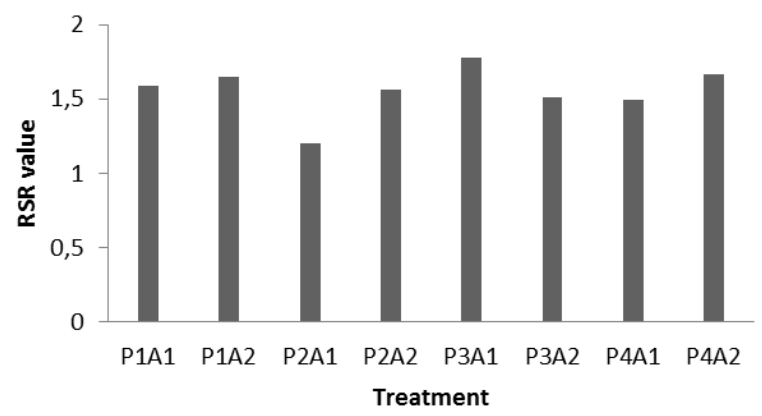

Figure 2 The average shoot-root- ratio of each treatment combination of the seedlings grown for 4 moths. NOTE: A1: tailing media; A2; mix media; P1: C. junghuniana; P2: P. merkusii; P3; M. azedarach; P4: G. arborea;

Figure 2 shows that in general the value of SRR of seedlings grown in tailing media (A1) was lower than in mix media (A2) with exception of $M$. azedarach. The highest SRR value was P3A1(M. azedarach in tailing media) at 1.79. The average value of SRR was between 1.2-1.8 which means that each treatment had provided good seedling growth. According to Duryea and Brown (1984) in Setyaningsih (2007) seedling growth and ability is best at SRR value between 1-3 meaning that the growth is in balance between water and nutrient absorption by the roots and transpiration done by leaves.

Survival percentages from the first month up to four months observation were given in Table 8. Most plant species could survive and grow well in the media studied.

Table 8 Survival percentage of four plant species grown on media containing tailing for 4 months

\begin{tabular}{lllllll} 
Treat & Amou & \multicolumn{5}{c}{ Percentage of survival (\%) } \\
\cline { 3 - 7 } ment & nt & 0 BST & 1 BST & 2 BST & 3 BST & 4 BST \\
\hline P1A1 & 30 & 100 & 100 & 100 & 100 & 100 \\
P1A2 & 30 & 100 & 100 & 100 & 100 & 100 \\
P2A1 & 30 & 100 & 100 & 100 & 96.67 & 83.33 \\
P2A2 & 30 & 100 & 100 & 100 & 100 & 96.67 \\
P3A1 & 30 & 100 & 100 & 100 & 96.67 & 96.67 \\
P3A2 & 30 & 100 & 100 & 100 & 96.67 & 76.67 \\
P4A1 & 30 & 100 & 100 & 100 & 100 & 100 \\
P4A2 & 30 & 100 & 100 & 96.67 & 96.67 & 96.67 \\
\hline NOTE: A1: tailing media; A2; & mix media; P1: $C$. \\
& junghuniana; P2: P. & Perkusii; P3; & M. \\
& azedarach; P4: G. arborea; & &
\end{tabular}

P. merkusii (P2) showed decreasing trend in survival starting on the $3^{\text {rd }}$ month on media tailing, while $M$. azedarach $(\mathrm{P} 3)$ and $G$. arborea $(\mathrm{P} 4)$ decrease slightly on the same time. This observation might indicate less ability of those plants to grow on tailing contained media.

\section{CONCLUSION}

Plant types significantly affect all growth parameters of seedlings on media containing tailing except shootroot ratio. Media types significantly affect diameter growth, total wet and dry biomass. Interaction between plant types and media have sifnificant effect on diameter growth, total wet and dry biomass. G. arborea gave the best growth response on all parameters except root-shoot-ratio and heigh growth compared to other species.

\section{REFERENCE}

Dharmawan IW. 2003. Pemanfaatan endomikoriza dan pupuk organik dalam memperbaiki pertumbuhan Gmelina arborea LINN pada tanah tailing [tesis]. Bogor: Sekolah Pascasarjana. Institut Pertanian Bogor.

Haryanti S. 2008. Respon pertumbuhan jumlah dan luas daun nilam (Pogostemon cablin. Benth) pada tingkat naungan yang berbeda. B. Anatomi dan Fsiologi. 16(2): 20-26.

Haryanti S. 2010. Jumlah dan distribusi stomata pada daun beberapa spesies tanaman dikotil dan monokotil. B. Anatomi dan Fsiologi. 18(2). 
Salisbury, Ross 1995. Fisiologi Tumbuhan Jiliid 3. Bandung: Penerbit Institut Teknologi Bandung.

Setyaningsih L. 2007. Pemanfaatan cendawan mikoriza arbuskula dan kompos aktif untuk meningkatkan pertumbuhan semai mindi (Melia azedarach Linn) pada media tailing tambang emas Pongkor [tesis]. Bogor: Sekolah Pascasarjana. Institut Pertanian Bogor.

Siregar UJ, Siregar CA. 2010. Fitoremediasi: Prinsip dan Prakteknya dalam Restorasi Lahan Paska
Tambang di Indonesia. Bogor (ID): SEAMEO BIOTROP.

Sitompul SM, Guritno B. 1995. Analisis Pertumbuhan Tanaman. Gadjah Mada University Press. Yogyakarta(ID).

Wasis B, Sandrasari A. 2011. Pengaruh pemberian pupuk kompos terhadap pertumbuhan semai mahoni (Swietenia macrophylla King.) pada media tanah bekas tambang emas (tailing). J. Silvikultur Tropika. 03(1): 109-112. Bogor (ID). 